\title{
Analisis Sebaran Lebar Karapas dan Proporsi Rajungan Betina Bertelur yang Tertangkap di Perairan Demak
}

\author{
Henrian Rizki Pradana*, Ria Azizah Tri Nuraini, Sri Redjeki \\ Departemen IImu Kelautan, Fakultas Perikanan dan IImu Kelautan, Universitas Diponegoro \\ Jl. Prof.H.Soedarto S.H, Tembalang,Semarang, Jawa Tengah 50275 Indonesia \\ ${ }^{*}$ Corresponding author, e-mail: henrian.rizki@gmail.com
}

\begin{abstract}
ABSTRAK : Rajungan merupakan komoditas perikanan bernilai ekonomis penting dan memiliki nilai komersial yang cukup tinggi. Salah satu desa yang memproduksi rajungan adalah Desa Betahwalang. Sebagian besar rajungan hasil tangkapan di perairan Betahwalang dikirim untuk di ekspor ke luar negeri. Tingginya permintaan pasar terhadap komoditas perikanan rajungan memicu eksploitasi yang berlebihan sehingga dapat berdampak terhadap kelestarian sumber daya rajungan. Tujuan penelitian ini adalah untuk menganalisis sebaran lebar karapas dan proporsi EBF (egg berried female) rajungan di Desa Betahwalang, Demak terkait dengan upaya pengelolaan rajungan secara berkelanjutan sesuai dengan Peraturan Menteri Kelautan dan Perikanan no. 1 tahun 2015. Penelitian ini dilaksanakan pada bulan Februari - Maret 2019 di Desa Betahwalang, Demak menggunakan metode random sampling. Pengukuran rajungan dilakukan di bakul yang ada di Desa Betahwalang, Demak. Hasil penelitian menunjukkan bahwa 1003 ekor rajungan (83\%) yang tertangkap berukuran $>10 \mathrm{~cm}$ dari total 1203 rajungan tertangkap. Nisbah kelamin di Desa Betahwalang menunjukkan bahwa antara jantan dan betina seimbang $(1: 1,06)$. Sedangkan untuk betina bertelur yang tertangkap (EBF) berjumlah 81 ekor rajungan (13\%).
\end{abstract}

Kata kunci : Portunus pelagicus, Lebar Karapas, Egg Berried Female

\section{Analysis of the Distribution of Carapace Width and the Proportion of Egg-laying Blue Crab that are Caught in Demak Waters}

\begin{abstract}
Blue Swimming Crab is one of fisheries commodity with highly important economical and commerce value. One of the village that produce blue crab is Betahwalang. Most of the crabs are exported. With high demand of blue crab resulting in over exploitation that affects the population of blue crab. The purpose of this research is to analyze the spread of carapace width and the proportion of EBF (Egg Berried Female of the blue swimming crab in Desa Betahwalang, Demak that are related with the continuous management effort of blue crab consistent with Peraturan Menteri Kelautan dan Perikanan No 1 Tahun 2015. This research was conducted on February - March 2019 at Desa Betahwalang, Demak using random sampling method. The measurement of blue crab was done on the buyer at Desa Betahwalang, Demak. The results show that 1003 blue crab (83\%) that were caught had carapace width more than $10 \mathrm{~cm}$ from 1203 blue crab caught. The ratio of male and female crab show that male and female were equal $(1: 1,06)$. For the egg berried female (EBF) that were caught shows 81 blue crab caught (13\%).
\end{abstract}

Keywords: Portunus pelagicus, Carapace Width, Egg Berried Female

\section{PENDAHULUAN}

Tingginya hasil produksi perikanan tangkap laut Indonesia membuat Indonesia memiliki peluang sebagai salah satu negara pengekspor produk perikanan. Salah satu hasil laut yang banyak di ekspor adalah rajungan (Portunus pelagicus). Rajungan yang digunakan untuk kepentingan ekspor sampai saat ini masih mengandalkan hasil tangkapan dari laut. Nilai ekonomis rajungan yang tinggi berbanding lurus dengan upaya penangkapan yang semakin meningkat, sehingga dikhawatirkan dapat berdampak pada populasi dan struktur ukuran rajungan di alam (Hamid et al., 2015). Tingginya permintaan pasar terhadap komoditas perikanan rajungan memicu 
eksploitasi yang berlebihan sehingga dapat berdampak terhadap kelestarian sumber daya rajungan. Penangkapan rajungan di Lampung Timur oleh nelayan yang dilakukan tanpa memperhatikan ukuran lebar karapas dan kondisi rajungan betina yang sedang mengerami telur (egg berried female) dapat mengganggu penambahan stok baru (Zairion, 2014).Rendahnya pengetahuan nelayan di daerah Brebes dan masih lemahnya aturan-aturan pengendalian penangkapan oleh pemerintah berkaitan dengan aspek reproduksi, ukuran layak tangkap dan tingkat pemanfaatan rajungan, mengakibatkan eksploitasi dilakukan tanpa kendali. Nelayan melakukan penangkapan rajungan sepanjang tahun tanpa memperhatikan tempat dan waktu pemijahan serta ukuran rajungan yang ditangkap. Hal tersebut dapat mempengaruhi kelestarian rajungan di alam, apalagi jika terjadi tangkap lebih secara terus menerus. Penelitian ini bertujuan untuk menganalisis sebaran lebar karapas dan proporsi EBF (egg berried female) rajungan yang tertangkap di Perairan Demak terkait dengan upaya pengelolaan rajungan secara berkelanjutan sesuai dengan Peraturan Menteri Kelautan dan Perikanan no. 1 tahun 2015.

\section{MATERI DAN METODE}

Pengukuran rajungan dilakukan di pengepul yang ada di perairan Desa Betahwalang, Kabupaten Demak. Pengumpulan sampel rajungan menggunakan metode random sampling terhadap hasil tangkapan nelayan bubu yang dijual ke pengepul. Pengepul dipilih secara acak yang berangkat pada hari pendataan dilakukan selama 1 bulan. Selanjutnya dipilih secara acak rajungan yang akan diukur lebar karapas dan kondisi reproduksinya. Pengamatan lebar karapas rajungan dilakukan dengan mengukur panjang antara ujung sisi duri lateral karapas ke ujung sisi duri lateral yang lain seperti yang ditunjukkan di Gambar 1 dengan menggunakan penggaris 30 $\mathrm{cm}$.

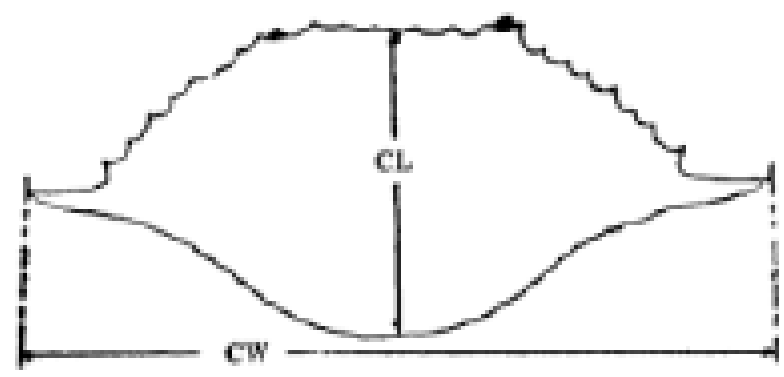

Gambar 1. Lebar (CW) dan Panjang (CL) Karapas Rajungan

Pengamatan rajungan betina bertelur (EBF) dilakukan dengan cara visual terhadap rajungan betina yang sedang mengerami telur di abdomen flop-nya berdasarkan pedoman Kunsook et al (2014). Perhitungan sebaran lebar karapas rajungan dilakukan dengan menentukanselang kelas ukuran ( $\mathrm{mm}$ ). Penentuan selang kelas dapat dilakukan denganmencari jumlah kelas menggunakan persamaan yang dikemukakan oleh Sturgess dalam Supranto (2000).

$$
\Sigma=1+3,32 \log n
$$

Keterangan : $\Sigma=$ Jumlah Kelas; $\mathrm{n}=$ Jumlah Rajungan (ekor)

Jumlah kelas digunakan dalam mencari ukuran lebar kelas untuk menentukanselang kelas dengan rumus :

$$
\begin{aligned}
\mathrm{LK} & =\frac{\text { nilai terting } i-\text { nilai terendah }}{\Sigma} \\
\text { Keterangan }: \mathrm{LK}=\text { Lebar Kelas } ; \Sigma & =\text { Jumlah Kelas }
\end{aligned}
$$

Nisbah kelamin adalah perbandingan antara jumlah rajungan jantan danjumlah rajungan betina yang menyusun suatu populasi. Penghitungan nisbahkelamin dilakukan dengan membandingkan jumlah rajungan jantan terhadaprajungan betina. Selanjutnya untuk mengetahui 
apakah nisbah kelamin dalamkondisi seimbang dapat digunakan uji khi kuadrat (Steel dan Torie, 1989). Rumus yang digunakan adalah :

$$
X^{2}=\Sigma \frac{(O i-e i)^{2}}{e i}
$$

Keterangan $: \mathrm{O}=$ frekuensi rajungan jantan dan betina yang teramati; ei $=$ frekuensi harapan, yaitu frekuensi rajungan jantan ditambah betina dibagi dua; $X^{2}=$ sebuah nilai bagi peubah acak $X^{2}$ yang sebaran penarikan contohnya menghampiri sebaran $X^{2}$

Hipotesis yang diuji adalah :

Ho: Nisbah kelamin dalam kondisi seimbang (rasio kelamin 1: I)

$\mathrm{Hi}$ : Nisbah kelamin tidak dalam kondisi seimbang (rasio kelamin bukan 1:1)

Proporsi EBF adalah persentase jumlah rajungan betina yang sedang mengerami telur (EBF) terhadap jumlah seluruh rajungan betina. Rumus yang digunakan adalah :

$$
\mathrm{EBF}=\frac{\Sigma B T}{\Sigma^{B}} \times 100 \%
$$

Keterangan : BT = Jumlah rajungan betina yang mengerami telur (ekor); $\mathrm{B}=$ Jumlah total rajungan betina (ekor)

\section{HASIL DAN PEMBAHASAN}

Hasil penelitian yang dilakukan selama 1 bulan di Desa Betahwalang, Demak memperoleh 1203 rajungan yang terbagi dalam 10 kelas ukuran sebaran lebar karapas $(\mathrm{cm})$, nilai tengah ukuran kelas dan jumlah rajungan di masing-masing kelas yang dapat dilihat pada Tabel 1 berikut ini.

Seperti yang terlihat di Tabel 1 terdapat 10 kelas untuk sebaran lebar karapas rajungan mulai dari $6 \mathrm{~cm}$ sampai dengan $15.9 \mathrm{~cm}$. Interval per ukuran ditentukan dengan menggunakan rumus sesuai dengan metode dan didapatkan intervalnya adalah 0,9. Jumlah rajungan terbanyak berada di kelas $10-10,9 \mathrm{~cm}$ sebanyak 340 ekor rajungan. Kelas dengan jumlah rajungan paling sedikit adalah di kelas lebar $6-6,9$ dengan jumlah rajungan 1 ekor. Nilai tengah dari ukuran lebar rajungan yang didapat adalah $11,45 \mathrm{~cm}$.

Berdasarkan hasil yang didapat untuk rajungan berukuran dibawah $10 \mathrm{~cm}$ yang tertangkap dengan jumlah paling sedikit terdapat pada rentang kelas $6-6,9 \mathrm{~cm}$ yang berjumlah 1 ekor rajungan. Sedangkan rajungan dengan ukuran diatas $10 \mathrm{~cm}$ yang tertangkap dengan jumlah paling sedikit adalah di rentang kelas $15-15,9 \mathrm{~cm}$ berjumlah 6 ekor rajungan. Total rajungan dengan ukuran dibawah $10 \mathrm{~cm}$ yang tertangkap adalah 200 ekor rajungan (17\%). Sedangkan rajungan yang berukuran diatas $10 \mathrm{~cm}$ yang tertangkap dengan jumlah total 1003 ekor rajungan (83\%).

Tabel 1. Distribusi Sebaran Lebar Karapas Rajungan (Portunus pelagicus)

\begin{tabular}{lccccc}
\hline \multirow{2}{*}{ No } & \multirow{2}{*}{ Kelas L $(\mathrm{cm})$} & \multirow{2}{*}{ Nilai Tengah } & Jumlah (ekor) & \multicolumn{2}{c}{ Jenis Kelamin } \\
\cline { 5 - 6 } & & & & Male & Female \\
\hline 1 & $6-6.9$ & 6.45 & 1 & $0 \%$ & $100 \%$ \\
2 & $7-7.9$ & 7.45 & 51 & $54 \%$ & $46 \%$ \\
3 & $8-8.9$ & 9.45 & 135 & $69 \%$ & $31 \%$ \\
4 & $9-9.9$ & 3.45 & 328 & $53 \%$ & $47 \%$ \\
5 & $10-10.9$ & 10.45 & 215 & $45 \%$ & $54 \%$ \\
6 & $11-11.9$ & 11.45 & 92 & $51 \%$ & $55 \%$ \\
7 & $12-12.9$ & 12.45 & 22 & $52 \%$ & $49 \%$ \\
8 & $13-13.9$ & 14.45 & 6 & $23 \%$ & $77 \%$ \\
9 & $14-14.9$ & 15.45 & 1203 & $33 \%$ & $67 \%$ \\
10 & $15-15.9$ & & & $49 \%$ & $51 \%$ \\
\hline
\end{tabular}


Rajungan paling banyak tertangkap berada di kelas ukuran $10-10,9 \mathrm{~cm}$ sebanyak 340 ekor rajungan (28\%). Kelas kedua yang paling banyak tertangkap ada di rentang kelas ukuran 11 11,9 sebanyak 267 ekor rajungan (27\%). Sedangkan kelas ketiga paling banyak ada di rentang kelas ukuran 12 - 12,9 berjumlah 215 ekor rajungan (17\%).Menurut Permen KP No 1 Tahun 2015 bahwa rajungan yang boleh ditangkap adalah rajungan Portunus pelagicus dengan ukuran lebar karapas diatas $10 \mathrm{~cm}$. Rajungan yang ditangkap selama penelitian sebagian besar berukuran diatas $10 \mathrm{~cm}$. Meskipun rajungan yang tertangkap banyak yang berukuran diatas $10 \mathrm{~cm}$, tetapi masih ada juga rajungan yang tertangkap dengan ukuran dibawah $10 \mathrm{~cm}$.

Rajungan dengan ukuran dibawah $10 \mathrm{~cm}$ masih tertangkap dan tidak dilepas. Hal ini dikarenakan nelayan dan pengepul yang belum sepenuhnya sadar dari diberlakukannya Permen KP No 1 Tahun 2015. Biasanya nelayan dan pengepul langsung menimbang rajungan yang ditangkap. Rajungan dituang ke timbangan lalu direbus. Walaupun terlihat bahwa ada rajungan dengan lebar karapas yang kecil, pengepul dan nelayan tidak akan membuang rajungan itu. Karena akan merugikan pengepul dan nelayan dari segi timbangan dan pendapatan.

Penangkapan rajungan dibawah ukuran $10 \mathrm{~cm}$ sangat disayangkan karena rajungan pada ukuran tersebut merupakan rajungan yang belum matang gonad. Hamid (2015) menyatakan bahwa tingkat eksploitasi rajungan yang melewati batas optimum atau telah terjadi tangkap lebih (overfishing) berdampak pada penurunan keberhasilan perkawinan dan pemijahan rajungan. Rajungan yang tertangkap dan berukuran kecil merupakan rajungan belum matang gonad, sehingga berpotensi menurunkan keberlanjutan populasi rajungan. Penangkapan rajungan dengan ukuran tidak standar masih dilakukan oleh banyak nelayan. Hal ini dikarenakan tidak adanya pengawasan yang dilakukan oleh pihak berwajib. Tidak adanya sanksi yang jelas juga menyebabkan penangkapan masih terus dilakukan. Hukum desa yang ada pun juga tidak mencantumkan hukuman yang berat.

\section{Distribusi Rajungan Portunus pelagicus}

Sebaran berat rajungan terbagi menjadi 11 kelas ukuran berat, nilai tengah kelas dan jumlah rajungan di masing-masing kelas. Tabel 2 memperlihatkan sebaran berat rajungan yang didapat selama penelitian. Seperti yang terlihat di Tabel 2 bahwa distribusi sebaran berat rajungan dibagi menjadi 11 kelas dan dimulai dari kelas ukuran berat 23 - 51 gram hingga $313-341$ gram. Interval kelas yang didapat dari hasil perhitungan adalah 28 . Kelas dengan jumlah rajungan tertangkap yang terbanyak adalah di kisaran berat $52-80$ gram dengan jumlah 395 ekor rajungan. Rajungan terberat yang tertangkap berjumlah 1 ekor di kelas 313 - 341 gram dan rajungan teringan berada di kelas 23 -51 gram berjumlah 126 ekor. Nilai tengah dari ukuran berat rajungan adalah 177 gram. Rajungan

Tabel 2. Distribusi Sebaran Berat Rajungan (Portunus pelagicus)

\begin{tabular}{lccc}
\hline No & Kelas Berat (gram) & Nilai Tengah & Jumlah (ekor) \\
\hline 1 & $23-51$ & 37 & 126 \\
2 & $52-80$ & 66 & 395 \\
3 & $81-109$ & 95 & 274 \\
4 & $110-138$ & 124 & 237 \\
5 & $139-167$ & 153 & 103 \\
6 & $168-196$ & 182 & 36 \\
7 & $197-225$ & 211 & 18 \\
8 & $226-254$ & 240 & 8 \\
9 & $255-283$ & 269 & 2 \\
10 & $284-312$ & 298 & 3 \\
11 & $313-341$ & 327 & 1 \\
& Jumlah & \multicolumn{2}{c}{1203} \\
\hline
\end{tabular}


Tabel 3. Distribusi Sebaran Lebar Karapas Betina

\begin{tabular}{ccccccc}
\hline \multirow{2}{*}{ No } & \multirow{2}{*}{ Kelas Lebar } & \multirow{2}{*}{ Nilai Tengah } & \multirow{2}{*}{ Jumlah } & \multicolumn{4}{c}{ Tingkat Kematangan Gonad } \\
\cline { 5 - 7 } & & & & I & II & III \\
\hline 1 & $10-10.6$ & 10.3 & 134 & $4 \%$ & $83 \%$ & $13 \%$ \\
2 & $10.7-11.3$ & 11 & 136 & $1 \%$ & $86 \%$ & $13 \%$ \\
3 & $11.4-12$ & 11.7 & 113 & $0 \%$ & $90 \%$ & $10 \%$ \\
4 & $12.1-12.7$ & 12.4 & 73 & $0 \%$ & $86 \%$ & $14 \%$ \\
5 & $12.8-13.4$ & 13.1 & 39 & $0 \%$ & $72 \%$ & $28 \%$ \\
6 & $13.5-14.1$ & 13.8 & 20 & $0 \%$ & $85 \%$ & $15 \%$ \\
7 & $14.2-14.8$ & 14.5 & 14 & $0 \%$ & $57 \%$ & $43 \%$ \\
8 & $14.9-15.5$ & 15.2 & 4 & $0 \%$ & $50 \%$ & $50 \%$ \\
& Total Rajungan Betina & 533 & $1 \%$ & $84 \%$ & $15 \%$ \\
\hline
\end{tabular}

betina berjumlah 619 ekor selanjutnya terbagi menjadi 10 kelas ukuran sebaran lebar karapas, nilai tengah kelas dan jumlah rajungan di masing-masing kelas seperti yang terlihat pada Tabel 3 . Setelah diketahui distribusi sebaran lebar karapas semua jenis kelamin, selanjutnya dicari distribusi sebaran lebar karapas betina. Dari data yang diambil maka didapatkan tabel distribusi sebaran lebar karapas betina. Rajungan betina yang didapat selama penelitian adalah 619 ekor rajungan. Dilihat dari tabel 3 jumlah terbanyak rajungan betina yang didapatkan adalah 196 ekor rajungan di kelas lebar 10,7 - $11.6 \mathrm{~cm}$. Rajungan betina yang tertangkap diatas ukuran $10 \mathrm{~cm}$ berjumlah 533 ekor rajungan dan rajungan betina dibawah ukuran $10 \mathrm{~cm}$ yang tertangkap berjumlah 86 ekor.

Budiaryani (2007) menyatakan bahwa ukuran rajungan berdasarkan lebar karapasnya dikelompokkan menjadi 3 fase yaitu rajungan dengan ukuran $<6 \mathrm{~cm}$ merupakan rajungan fase juvenil, ukuran $6-12 \mathrm{~cm}$ merupakan rajungan muda dan rajungan berukuran $>12 \mathrm{~cm}$ merupakan rajungan pada fase dewasa. Menurut Fauzi et al. (2018) penelitian yang dilakukan di Teluk Banten mendapatkan total 501 ekor rajungan betina (50\%). Dari jumlah total tersebut terdapat 169 ekor rajungan betina yang berukuran diatas $12 \mathrm{~cm}$ (34\%). Rajungan betina yang tertangkap di Betahwalang dengan ukuran $>12 \mathrm{~cm}$ berjumlah 170 ekor (27\%). Dari data diatas dapat kita lihat bahwa rajungan betina dengan ukuran lebih dari $12 \mathrm{~cm}$ di perairan Betahwalang memiliki jumlah yang lebih kecil dibandingkan dengan penelitian di daerah lain dengan persentasi $27 \%$. Dari hal tersebut, maka dapat dilihat bahwa sumberdaya rajungan di Betahwalang sudah mengalami over eksploitasi. Jumlah nelayan yang banyak dan sumberdaya yang sedikit akan semakin mengurangi populasi rajungan.

Secara tidak langsung nelayan dilarang menangkap rajungan kecil karena dapat menurunkan ketersediaan rajungan. Kelangsungan hidup rajungan kecil tidak akan sampai dewasa untuk dapat berkembang biak. Jika hal ini terus dilakukan maka akan mengakibatkan populasi rajungan menurun dan habis. Kemungkinan habisnya populasi rajungan di Desa Betahwalang, Demak tentunya tidak akan terjadi dalam waktu beberapa bulan kedepan. Tapi hal ini akan terjadi dalam hitungan tahun. Habisnya populasi rajungan juga akan semakin cepat jika nelayan yang memakai arad masih diijinkan untuk melaut. Alat tangkap arad dapat mempercepat turunnya populasi rajungan karena sebagian besar hasil tangkapan rajungan dari nelayan arad memiliki ukuran dibawah $10 \mathrm{~cm}$.

\section{Tingkat Kematangan Gonad dan Proporsi EBF Rajungan}

Penelitian yang telah dilakukan dari Bulan Februari - Maret 2019 mendapatkan total rajungan berjumlah 1203 ekor. Dimana dari 1203 ekor rajungan tersebut, 619 ekor merupakan rajungan berkelamin betina. Setelah diketahui distribusi sebaran lebar karapas dari rajungan betina maka selanjutnya rajungan betina dipisahkan berdasarkan tingkat kematangan gonadnya (TKG). Klasifikasi tingkat kematangan gonad (TKG) mengacu pada pedoman kematangan gonad (Kunsook et al., 2014). Berdasarkan pedoman kematangan gonad maka pada TKG 1 didapatkan 53 ekor rajungan, untuk TKG 2 didapatkan rajungan berjumlah 485 ekor dan di TKG 3 terdapat sebanyak 81 ekor rajungan. 
Hasil penelitian menunjukkan bahwa di Betahwalang diperoleh rajungan sebanyak 584 rajungan jantan dan 619 rajungan betina dengan nisbah kelamin $1: 1,06$. Berdasarkan uji chi square yang dilakukan pada selang kepercayaan 95\% diperoleh bahwa $X_{\text {hitung }}<X_{\text {tabel }}$ (lampiran). Dari uji ini bisa dilihat bahwa jumlah jantan dan betina seimbang. Nisbah kelamin yang ideal antara jantan dan betina adalah 1 : 1, namun hal ini terkadang berbeda dengan kondisi di alam. Perbandingan nisbah kelamin di alam tidak akan mutlak karena dapat dipengaruhi oleh ketersediaan makanan, keseimbangan rantai makanan dan kepadatan populasi (Effendie, 2002).

Pada Gambar 2 bisa dilihat grafik TKG dari rajungan betina yang dibagi menjadi 3 kelas kematangan gonad. Tingkat kematangan 1 adalah rajungan yang belum matang (Immature) dan tingkat kematangan 2 adalah rajungan yang sudah berisi gonad tapi belum berada di luar abdomen sedangkan tingkat kematangan 3 adalah rajungan yang telurnya sudah berada di luar abdomen dan biasanya berwarna oranye sampai hitam.

Dari grafik tersebut dapat dilihat bahwa rajungan betina yang tertangkap paling banyak adalah rajungan pada tingkat kematangan 2 sebanyak 485 ekor rajungan (78\%). Rajungan dengan jumlah terbanyak kedua adalah rajungan betina di tingkat kematangan 3 yang berjumlah 81 ekor rajungan (13\%). Tingkat kematangan 1 merupakan tingkat yang memiliki jumlah rajungan tertangkap paling sedikit dengan jumlah 53 ekor rajungan (9\%). Seperti yang terlihat pada Gambar 2, rajungan dengan TKG 3 berjumlah 81 ekor. Dari hasil ini maka didapatkan proporsi BEF rajungan di Betahwalang sebesar 13\%. Proposi ini menunjukkan bahwa $13 \%$ dari betina tertangkap adalah betina bertelur.

Menurut Permen No 1 Tahun 2015 menyatakan bahwa rajungan yang boleh ditangkap adalah rajungan yang tidak bertelur sedangkan untuk rajungan bertelur yang tertangkap maka harus dilepaskan. Pelepasan kepiting bertelur atau kepiting TKG 3 dilakukan agar populasi rajungan tidak menurun. Romimohtarto (1997) menyatakan bahwa rajungan yang telurnya sudah berada di luar abdomen dan berwarna hitam akan menetas dalam waktu $1-4$ hari sedangkan rajungan yang telurnya berwarna oranye meskipun berada di luar abdomen maka telur akan menetas dalam waktu 7 hari. Sementara menurut Zairion (2014) menyatakan bahwa telur yang telah dibuahi memerlukan waktu 8 hari untuk menetas. Jika betina bertelur tidak dilepas, maka akan berdampak buruk pada keberlanjutan populasi rajungan.

Jika betina bertelur tidak dilepas, maka akan berdampak buruk pada keberlanjutan populasi rajungan. Menurut Saputra et al (2009) bahwa intensitas penangkapan perlu dibatasi agar tidak mengarah pada recruitment overfishing, yaitu apabila kegiatan perikanan banyak menangkap rajungan-rajungan yang telah matang gonad sehingga rajungan tidak memiliki kesempatan untuk bereproduksi.

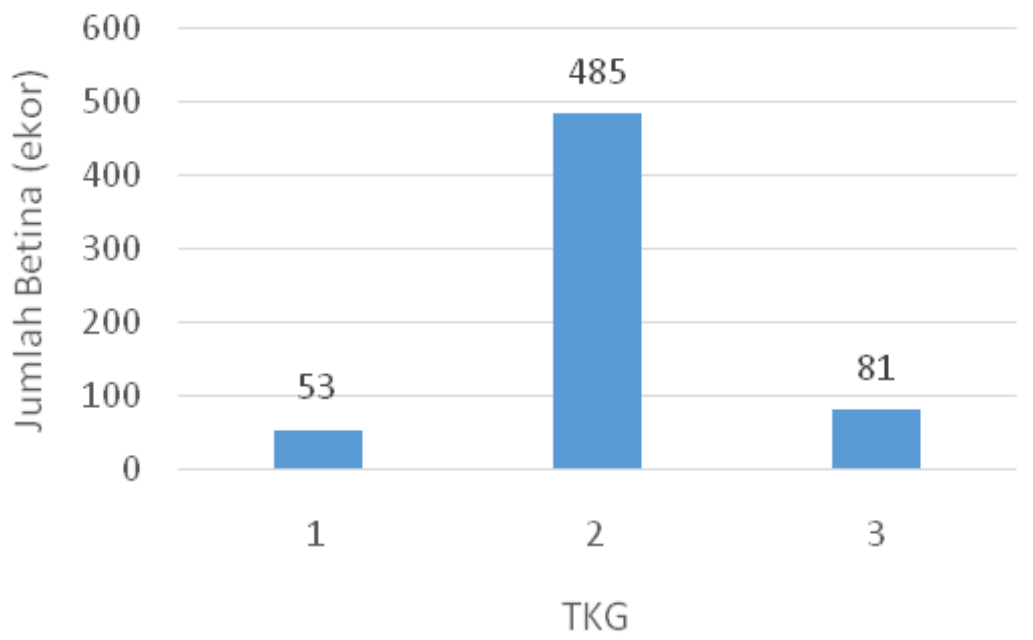

Gambar 1. Grafik yang didapatkan setelah menghitung jumlah rajungan dimasing-masing TKG 


\section{KESIMPULAN}

Bahwa rajungan yang tertangkap di Desa Betahwalang, Demak berukuran mulai dari 6,-16,4 $\mathrm{cm}$ dan terdapat 1003 ekor rajungan (83\%) berukuran diatas $10 \mathrm{~cm}$ dari 1203 rajungan tertangkap, akan tetapi masih ada rajungan dengan ukuran dibawah $10 \mathrm{~cm}$ yang tertangkap, kondisi ini menyalahi Peraturan Pemerintah Kelautan dan Perikanan No 1 Tahun 2015 yang mensyaratkan bahwa dilarang menangkap rajungan dengan ukuran dibawah $10 \mathrm{~cm}$. Rajungan betina yang tertangkap di Desa Betahwalang, Demak berjumlah 619 ekor dimana 81 ekor (13\%) rajungan tersebut berada pada TKG 3, yaitu rajungan yang telurnya sudah berada di abdomen flap rajungan (EBF).

\section{UCAPAN TERIMAKASIH}

Artikel ini merupakan bagian dari skripsi yang berjudul "Analisis Sebaran Lebar Karapas dan Proporsi EBF (Egg Berried Female) Rajungan, Portunus Pelagicus yang Tertangkap di Perairan Demak". Sebagai syarat memperoleh gelar Sarjana Strata satu Departemen IImu Kelautan, Fakultas Perikanan dan Ilmu Kelautan, Universitas Diponegoro.

\section{DAFTAR PUSTAKA}

Budiaryani N.R. 2007. Kajian Perikanan Rajungan di Perairan Semarang. Semarang (ID): BBPPI. Effendie, M.I. 2002. Biologi Perikanan. Yayasan Pustaka Nusatama. Yogyakarta. $163 \mathrm{hlm}$.

Fauzi, M.J., Gaffar, A., Erdyanto, B., Dhewang, I.B., Arafat, M.A., Akmalia, D.A. \&Triyono, H. 2018. Pendugaan Growth Overfishing Rajungan (Portunus pelagicus) di Teluk Banten. Jurnal Perikanan dan Kelautan. 8(1):96-103.

Ferdiansyah. 2017. Perbandingan Hasil Tangkapan Bubu Lipat Kotak dengan Bubu Lipat Kubah Terhadap Hasil Tangkapan Rajungan (Portunus pelagicus) di Perairan Rembang, Jawa Tengah. Jurnal Perikanan Tangkap. 1(1):1-8

Hamid, A. \& Wardiatno, Y. 2015. Population Dynamics of the Blue Swimming Crab (Portunus pelagicus Linnaeus, 1758) in Lasongko Bay, Central Buton, Indonesia. AACL Bioflux, 8(5):729-739.

Kementerian Kelautan dan Perikanan. 2015. Peraturan Menteri Kelautan dan Perikanan Nomor 1 Tahun 2015 tentang Penangkapan Lobster (Panulirus spp.), Kepiting (Scylla spp.), dan Rajungan (Portunus pelagicus spp.). Jakarta (ID): Kementerian Kelautan dan Perikanan. 5 hlm.

Kunsook, C., Nantana, G., \& Nittharatana, P. 2014. A Stock Assessment of the Blue Swimming Crab Portunus pelagicus (Linnaeus, 1758) for Sustainable Management in Kung Krabaen Bay, Gulf of Thailand. Tropical Life Sciences Research, 25(1):41-59.

Saputra, S.W. 2009. Buku Ajar Berbasis Riset Dinamika Populasi Ikan. Universitas Diponegoro. Semarang.

Steel, R. \& Torrie, J.H. 1989. Prinsip dan prosedur statistika. Diterjemahkan oleh Bambang Sumantri. Gramedia Pustaka. Jakarta. Hal:772.

Supranto, J. 2000. Statistik Teori dan Aplikasi Jilid Keenam. Jakarta : Erlangga

Zairion, Z., Wardianto, Y., Fahrudin, A. \& Boer, M. 2014. Distribusi Spasio Temporal Populasi Rajungan (Portunus pelagicus) Betina Mengerami Telur di Perairan Pesisir Lampung Timur. Bawal 6 (2):95-102 